\title{
EXOGENOUS SALICYLIC ACID TREATMENTS ENHANCE TOLERANCE TO SALINITY OF WHEAT (TRITICUM AESTIVUM) PLANTLETS.
}

\author{
Cornelia Purcărea ${ }^{1}$, Dorina Cachiță², Adriana Petruş ${ }^{3}$, Liviu Pop $^{3}$, Adriana Chis $^{1}$ \\ ${ }^{1}$ University of Oradea - Faculty of Environmental Protection, 26 General Magheru str., Oradea, neli_oradea@yahoo.com \\ ${ }^{2}$ Vasile Goldiş West University Arad \\ ${ }^{3}$ University of Oradea, Faculty of Science
}

Key words: wheat, salicylic acid, root, growth, antioxidant enzymes, proline.

Summary

Salt stress, an abiotic stress, determines modifications of some biochemical indicators, like, antioxidant enzymes, proline (amino acid accumulate in higher plants under salinity stress) content, and some physiological processes including: plant growth and development. In this paper we studied the influence of exogenous treatment of wheat seeds, with $0.1 \mathrm{mM}$ salicylic acid (SA) solution, in the plant response to salt stress. The treatment was applied by presoaking the seeds in the treatment solution for 12 hours before germination. The results showed that exogenous $0.1 \mathrm{mM}$ SA solution, administrated to the wheat cariopses significantly ameliorated the negative effect of salt stress in first week of germination in laboratory conditions..

\section{INTRODUCTION}

Salicylic acid (SA) acts as a potential non-enzymatic antioxidant as well as a plant growth regulator. Plant growth and development was intensly affected by different adverse environmental conditions and by pathogens. In plants the damaging effects of these abiotic and biotic stress factors take the shape of alterations in the plant physiology which leads to a reduction of growth and a decrease of their bioproductivity. Salicylic acid could ameliorate the damaging effects of heavy metals in rice (Mishra and Choudhuri, 1999), drought stress in wheat (Waseem et al,2006) and salt stress in wheat (Arfan et al, 2007) and in sunflower plants (Noreen et al, 2009).

The application of Salicylic Acid, Acetylsalicylic Acid or other analogues of SA, to leaves of maize and soybean accelerated the growth of their leaf area, and the dry mass production, but plant height and root length remained unaffected (Khan et al. 2003). Out of the various concentrations of SA solutions used, Fariduddin et al. 2003, observed maximum increase in dry matter accumulation at a concentration of $10^{-5} \mathrm{M}$, supplemented to the leaves of the standing plants of Brassica juncea, but any concentration higher than this proved to have an inhibitory effect.

Purcărea and Cachiță 2008a, studying the influence of Salicylic acid (SA) and Acetylsalicylic acid (ASA), on the growth of sunflower (Helianthus sp.) seedling roots, on their total absorption capacity and on content of assimilatory pigments in the primary leaves, observed that diluted ASA solution, with $0.01 \mathrm{mM}$ and $0.1 \mathrm{mM}$ concentration determined an increase in the total chlorophyllian and carotenoid pigments content in the primary leaves of sunflower plantlets especially for $0.01 \mathrm{mM}$ and $0.1 \mathrm{mM}$ concentrations. Higher concentrations than 0.5 $\mathrm{mM}$ decreased the same parameter, the greatest inhibitions being obtained for the SA or ASA solutions of a 5.0 mM concentration. The same authors Purcărea and Cachiță in 2008b, comparing the effects of the two solutions observed that on the $6^{\text {th }}$ day of germination the diluted ASA solutions, with concentrations of $0.01,0.1$ si $0.5 \mathrm{mM}$ had greater effects, the highest increase of the total absorption capacity of sunflower root system, with $159.6 \%$ compared to the control lot being recorded in case of the treatment with $0.1 \mathrm{mM}$ ASA solution.

Significant increases of the root growth were found after spraying SA on leaves and in soybean plants by Gutiérrez-Coronado et al. 1998, and in carrot, radish, and beet plants by Gutiérrez-Rodríguez et al. 1991.

The effect of $\mathrm{NaCl}$ on the total peroxidase activity in a 5 day-old seedling of two contrasting genotypes of Setaria italica, was studied by Sreenivasulu et al. in 1999. They found that the total peroxidase activity increased under $\mathrm{NaCl}$ salinity.

However the leaves of corn and soybean treated with acetylsalicylic acid or gentisic acid exhibited no change in their chlorophyll contents (Khan et al, 2003). Salicylic acid activated the synthesis of carotenoids, xanthophylls and the rate of de-epoxidation, but decreased the level of chlorophyll pigments, both in wheat and moong plants and also the ratio of chlorophyll a/b in wheat plantlets (Moharekar et al, 2003).

Soaking the grains of wheat in $10^{-5} \mathrm{~m}$ of SA solution resulted in higher pigment contents in the plants which declined as the concentration of SA was increased above that concentration (Hayat et al 2005).

Xue Jianping et al., 2006, studied the effects of different concentrations of SA solution on the growth of Pinellia ternate. When the height of the plant was about $10 \mathrm{~cm}$, the leaves was sprayed with different concentrations of SA solution and measured height, total chlorophyll content, activity of SOD (superoxide dismutase), MDA (Malondiadehyde) content, photosynthesis rate, intercellular $\mathrm{CO}_{2}$ concentration, the transpiration rate and the leaf temperature. The results indicated that intercellular $\mathrm{CO}_{2}$ concentration increased, leaf temperature decreased and photosynthesis speed was good in a $0.5 \mathrm{mM} \mathrm{SA}$ solution. In conclusion, the concentration of $0.5 \mathrm{mM}$ SA solution was suitable for the growth of $P$. ternate. 
Proline, a protective, free amino acid, is one of the potential biochemical indicators of stress tolerance in plants. Proline contributes to membrane stability and mitigates the effect of $\mathrm{NaCl}$ on cell membrane disruption (Ashraf and Harris, 2004).

The aim of this work was to study the involvement of the exogenous applied SA solutions in wheat (Triticum aestivum sp.) plant response to salt stress.

The experiments were performed at the "Research Center of the Risk Factors for Agriculture, Forestry and Environment" in the Faculty of Environmental Protection, University of Oradea in 2010.

\section{MATERIALS AND METHODS}

Sample preparation - Wheat cariopses (Triticum aestivum cv.Crisana) were soaked for $12 \mathrm{~h}$ in water or in 0.1 mM SA.

The germination was made in plastic recipients, for 7 days, on a filter paper, moistened with $20 \mathrm{ml}$ treatment solution:

control lot $(\mathbf{C})-12 \mathrm{~h}$ soaked in water and germinated in water.

sample $1\left(\mathbf{S}_{1}\right)-12 \mathrm{~h}$ soaked in water and germinated in $200 \mathrm{mM} \mathrm{NaCl}$ solution;

sample $2\left(\mathbf{S}_{\mathbf{2}}\right)-12 \mathrm{~h}$ soaked in $0.1 \mathrm{mM} \mathrm{SA}$ and germinated in $200 \mathrm{mM} \mathrm{NaCl}$ solution.

Each recipient contained 20 seeds. The germination was made on filter paper moistened with tap water, at $20 \pm 3{ }^{\circ} \mathrm{C}$ in a Sanyo MLR $351 \mathrm{H}$ phytotron, day/night, and a relative of humidity $65-85 \%$, under natural photon flux density. Every day, the quantity of solutions from the recipients was brought to the level of $20 \mathrm{ml}$.

Growth measurement - For the biometrical determination, the length of the roots and shoots of 10 wheat seedlings was measured after 7 days of germination, and for each determination 3 repetitions were made.

Plant growth was estimated measuring the accumulation of root and shoot weight, after drying the plant material at $60^{\circ} \mathrm{C}$ for $72 \mathrm{~h}$. Relative water content was also measured and express according to the following equation:

$R W C(\%)=\frac{F W-D W}{F W} \cdot 100$

Preparation of enzyme extract - 0,5g fresh samples (roots and leaves) were collected from each variant in the $7^{\text {th }}$ day of germination, and were blended with $8 \mathrm{ml}$ phosphate buffer solution, $\mathrm{pH} 7.0$, diluted 1:9 with distilled water, cooled at $4^{\circ} \mathrm{C}$. The samples were centrifuged at $15000 \mathrm{x} \mathrm{g}$, for 20 minutes at $4^{\circ} \mathrm{C}$, and the supernatant was separated. The extract was kept in the refrigerator, for 2 hours for stabilizing and expressing enzyme activity.

Peroxidase $(P O X)$ activity determination - POX activity was determined at $30^{\circ} \mathrm{C}$, with a Shimadzu-UVmini-1240 spectrophotometer, following the formation of tetraguaiacol at $470 \mathrm{~nm}$ wavelength, $\varepsilon=26.6 \mathrm{mM}^{-1} \mathrm{~cm}^{-1}$, in a $3 \mathrm{ml}$ reaction mixture containing $1 \mathrm{ml}$ of $0.1 \mathrm{M}$ phosphate buffer, $\mathrm{pH}=6.0,1 \mathrm{ml} 15 \mathrm{mM}$ guaiacol, $1 \mathrm{ml}$ of 3 $\mathrm{mM} \mathrm{H} \mathrm{H}_{2} \mathrm{O}_{2}$, and $50 \mu \mathrm{l}$ of enzyme extract. One unit of peroxidase activity (U) represents the amount of enzyme catalyzing the oxidation of $1 \mu$ mole of guaiacol in $1 \mathrm{~min}$, method cited by Kim and Yoo, 1996.

Catalase activity determination - the decomposition of hydrogen peroxide was observed at $240 \mathrm{~nm}$, spectrophotometrically (Aeby,1984). For preparation of the plant extract $0.5 \mathrm{~g}$ plant material was homogenized with $3 \mathrm{ml} 0.1 \mathrm{M}$ Na-phosphate buffer $(\mathrm{pH}=6.5)$.

We measured into a quartz cuvette: $2 \mathrm{ml}$ above phosphate buffer $(\mathrm{pH}=6.5), 100 \mu$ hydrogen peroxide solution (12.5 $\mathrm{mM}$ concentration), $50 \mu \mathrm{l}$ plant extract. The solution was mixed, then the absorption change was registered for $3 \mathrm{~min}$ at $240 \mathrm{~nm}$. Slope value (reaction velocity: $\Delta$ Extinction per $\Delta$ time) was calculated.

Then:

activity $=\frac{2.15 m l}{0.05 m l} \cdot \frac{1}{0.004 m M} \cdot \frac{\Delta E}{\Delta t(\min .)} \cdot \frac{3 m l}{0.5 g}=6450 \frac{\Delta E}{\Delta t}$

where: $0.040 \mathrm{mM}^{-1} \mathrm{~cm}^{-1}$ is the extinction coefficient of $\mathrm{H}_{2} \mathrm{O}_{2}$ at $240 \mathrm{~nm}$; unit: $\mu$ mol hydrogen peroxide $\mathrm{g} \mathrm{FW}^{-1} \mathrm{~min}^{-1}$.

Proline determination - Proline was determined following Bates et al. (1973). For the proline determination 0.5 $\mathrm{g}$ of plant material was homogenized with $10 \mathrm{ml}$ of $3 \%$ aqueous sulfosalicylic acid and the homogenate was filtered through Whatman $\mathrm{nr} .2$ filter paper. $2 \mathrm{ml}$ of filtrate was treated with $2 \mathrm{ml}$ acid ninhydrin and $2 \mathrm{ml}$ glacial acetic acid in a test tube for 1 hour at $100^{\circ} \mathrm{C}$, and the reaction terminated in an ice bath. The reaction mixture was extracted with $4 \mathrm{ml}$ toluene, mixed vigorously with a test tube stirrer for 15-20 sec. The croophore containing toluene was aspired from the aqueous phase warmed to room temperature and the absorbance read at $520 \mathrm{~nm}$ using toluene for a blank. The proline concentration was determined from a standard curve and calculated on a fresh weight basis and expressed as $\mu$ moles proline/g of fresh weight material..

All the data in the present study are expressed as mean \pm sd obtained from 3 independent measurement. The results were statistically processed using the "t- test" using Prisma 5 for Windows, to compare the treatement means with control lot means. 


\section{RESULTS AND DISCUSSION}

Studying the growth of the embrionary roots of the wheat seedlings obtained from the seeds germination under laboratory conditions, after 7 days of germination, we observed that the salt treatments significantly reduced growth in length with $30.77 \%$, and decreased with $22.81 \%$ the relative water content of the wheat plantlets. In case of the seeds pre-treated with SA solutions of $0.1 \mathrm{mM}$ the negative effect of salt stress was reduced therefore the decrease of growth in length was insignificantly or only significantly reduced with $3.68 \%$, and RWC was insignificantly reduced, with 7.03\%, in comparison with the control lot (Table 1, Fig. 1).

Under stress condition, free proline (amino acid accumulate in higher plants under salinity stress) level increased in the leaves of wheat seedlings. Studying the value after spectrophotometrycal determination of proline content, we observed that under salt stress the proline content increased very significantly, with $105.9 \%$, in comparison with control lot. The treatment with $0.1 \mathrm{mM} \mathrm{SA}$ alleviated the effect of salt stress, and the free proline content in this condition was lower (with 75.22\%) than in case of salt stressed sunflower seedlings (Fig. 1 and 2).

Table 1.

Effect of Salicylic acid pre-treatment on the length ( $\mathrm{mm}$ ) and on relative water content (RWC \%) of wheat (Triticum aestivum sp.) seedling (root, shoot and plant length).

\begin{tabular}{|c|c|c|c|c|}
\hline $\begin{array}{l}\text { Statistic } \\
\text { evaluation }\end{array}$ & $\begin{array}{c}\text { Roots length } \\
(\mathrm{mm})\end{array}$ & $\begin{array}{l}\text { Shoots length } \\
(\mathrm{mm})\end{array}$ & $\begin{array}{l}\text { Plants length } \\
\quad(\mathrm{mm})\end{array}$ & RWC \% \\
\hline \multicolumn{5}{|c|}{ Type Control (C) } \\
\hline $\mathrm{M} \pm \mathrm{sd}$ & $112 \pm 2,91$ & $39.1 \pm 2.81$ & $197.9 \pm 3,2$ & $69.7 \pm 1.7$ \\
\hline \multicolumn{5}{|c|}{ Type $\mathrm{S}_{1}(\mathrm{NaCl} 0.2 \mathrm{M})$} \\
\hline $\mathrm{M} \pm \mathrm{sd}$ & $69.8 \pm 3.0$ & $36.1 \pm 1.75$ & $137 \pm 2.9$ & $53.8 \pm 0.9$ \\
\hline Statistical signification & *** & $* *$ & $* * *$ & $* * *$ \\
\hline \multicolumn{5}{|c|}{ Type $S_{2}(0.1 \mathrm{mM} S A+N a C l ~ 0.2 M)$} \\
\hline $\mathrm{M} \pm \mathrm{sd}$ & $108.5 \pm 2.1$ & $38.2 \pm 1.6$ & $190.6 \pm 2.0$ & $64.8 \pm 1.1$ \\
\hline Statistical signification & ns & ns & $*$ & $*$ \\
\hline
\end{tabular}

$\mathrm{M}=$ mean value; $\mathrm{sd}=$ standard deviation; $\mathrm{p}>0.05=\mathrm{ns}$ nonsignificant; $\mathrm{p}<0.05 *$ significant; $\mathrm{p}<0.01=* *$ distinctly significant; $\mathrm{p}<0.001=* * *$ very significant in comparison with control lot.

Figure 1. Percentage differences of plant length, relative water content (RWC) and proline content measured in wheat seedlings in stressed condition with or without SA treatment, in comparison with the same parameters measured in wheat seedlings from the control lot soaked in water. The value for the control lot was considered $100 \%$.

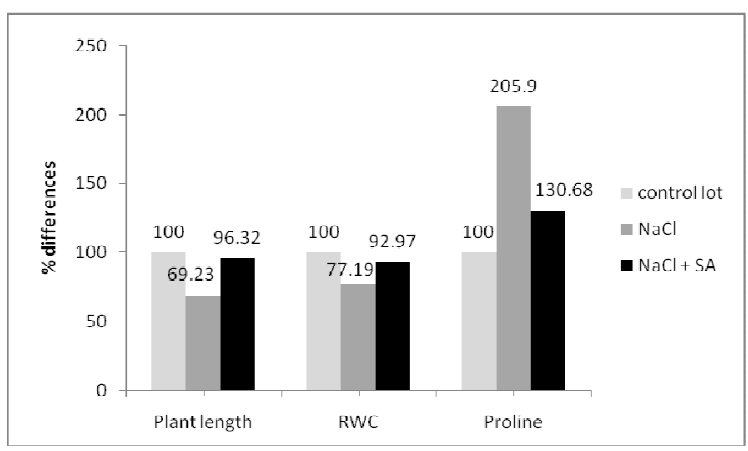

Figure. 2. Proline content in wheat seedling leaves in stressed or unstressed condition with or without SA treatment.

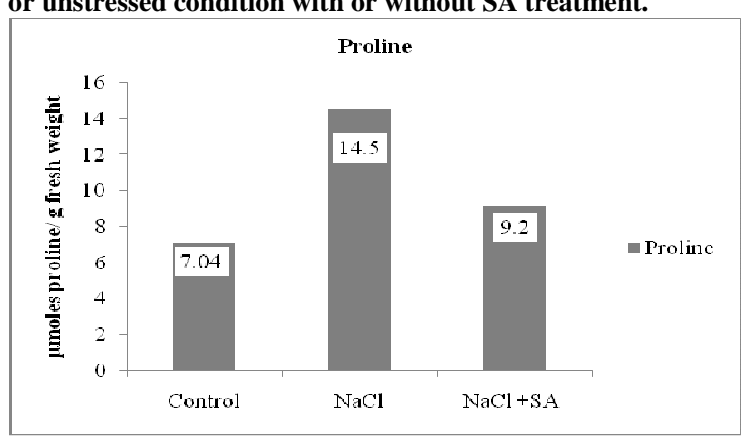


Studying the antioxidant enzymes activity in the case of samples treated with a $200 \mathrm{mM} \mathrm{NaCl}$ solution, a very significant increase of the peroxidase and catalase activity was registered (between 121.9 and $580.8 \%$, in comparison with the control lot), in the roots of wheat seedlings (table2, figure 3 ).

Table 2.

Estimative mean values for the antioxidant enzymes activity in roots and leaves of wheat seedlings on $7^{\text {th }}$ days of experiment, in comparison with the control lot treated with water

\begin{tabular}{|c|c|c|c|c|c|}
\hline \multirow{2}{*}{ Antioxidant enzymes } & \multirow{2}{*}{$\begin{array}{c}\text { vegetative } \\
\text { organs }\end{array}$} & \multirow{2}{*}{$\begin{array}{c}\text { Statistic } \\
\text { evaluation }\end{array}$} & \multicolumn{3}{|c|}{ Samples } \\
\hline & & & Control (C) & Salt (S1) & Salt +SA (S2) \\
\hline \multirow{3}{*}{ Peroxidase (POX) (U) } & \multirow{2}{*}{ root } & $\mathrm{M} \pm \mathrm{sd}$ & $0.393 \pm 0.007$ & $2.003 \pm 0.005$ & $0.412 \pm 0.023$ \\
\hline & & Statistic signification & N/A & *** & $*$ \\
\hline & leaf & Statistic signification & N/A & *** & $*$ \\
\hline \multirow{3}{*}{ Catalase (CAT) (U) } & \multirow{2}{*}{ root } & $\mathrm{M} \pm \mathrm{sd}$ & $4.29 \pm 0.034$ & $9.52 \pm 0.055$ & $4.41 \pm 0.078$ \\
\hline & & Statistic signification & N/A & $* * *$ & $*$ \\
\hline & leaf & Statistic signification & N/A & $* * *$ & $* * *$ \\
\hline
\end{tabular}

$\mathrm{M}=$ mean value; $\mathrm{sd}=$ standard deviation; $\mathrm{p}>0.05=$ nonsignificant; $\mathrm{p}<0.05 *$ significant; $\mathrm{p}<0.01=* *$ distinctly significant; $\mathrm{p}<0.001=* * *$ very significant in comparison with control lot.

The increase of peroxidase activity was higher than the increase of catalase activity. Salicylic acid pretreatment ameliorated the peroxidase and catalase activity under salt stress in enzyme extracts of wheat seedlings. Pre-soaking the wheat cariopses for $12 \mathrm{~h}$ in a $0.1 \mathrm{mM} \mathrm{SA}$ solution significantly reduced the increase of the peroxidase and catalase activity in the $7^{\text {th }}$ day of germination (the registered increase was between 2.8 and $110.08 \%$, in comparison with the control lot).

Figure 3. Percentage differences of antioxidant enzymes, POX and CAT activity, measured in roots and leaves of wheat seedlings in stressed condition with or without SA treatment, in comparison with the same parameters measured in the roots and leaves of wheat seedlings from the control lot soaked in water. The value for the control lot was considered $100 \%$.

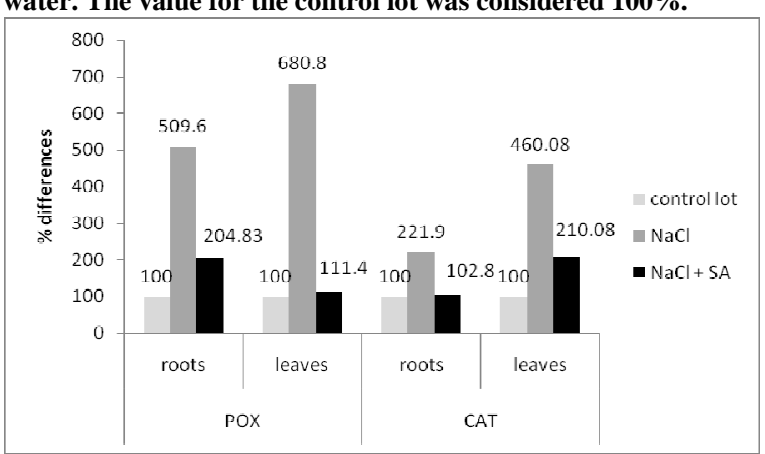

Similar results were obtained by Kaydan et al. in 2006. They observed that wheat seed soaking in SA increased shoot and root dry weight and osmotic potential in the salinity stressed wheat seedlings.

Fariduddin et al. in 2003 and Hayat et al in 2005, when studied the effect of exogenous SA and its derivatives on growth of Brassica junceea observed maximum increase in dry matter accumulation at a concentration of $0.01 \mathrm{mM} \mathrm{SA}$, supplemented to the leaves of the standing plants of Brassica juncea, but any concentration higher than this proved to have an inhibitory effect.

Hussein et al. 2007, spraying maize plants with salicylic acid in the rate of $200 \mathrm{ppm}$ improved all growth characters i.e. plant height, number and area of green leaves, stem diameter and dry weight of stem, leaves and whole plant.

Noreen et al. 2009, also found that exogenous foliar applied SA enhanced antioxidant capacity in salt stressed sunflower.

Proline can be used as a metabolic marker in relation to stress. Proline is produced immediately after encounter of cells with salt stress and protects the plasma membrane and proteins against stress Santoro et al 1992.

\section{CONCLUSIONS}

The analysis of the obtained results of this study shows that salt induced stress inhibits the growth parameters in wheat (Triticum aestivum cv. Crisana) seedlings, determined an increase in antioxidant enzymes, and in proline concentration.

$>$ The exogenous $0.1 \mathrm{mM}$ SA solution enhanced the growth of the wheat seedlings. 
$>$ The activity of antioxidant enzymes was significantly lower in SA treated seedlings in comparison with the salt stressed plantlets.

\section{ACKNOWLEDGEMENTS}

This work was cofinanced from the European Social Fund through Sectoral Operational Programme Human Resources Development 2007-2013, project number POSDRU/89/1.5/S/63258 "Postdoctoral school for zootechnical biodiversity and food biotehnology based on the eco-economy and the bio-economy required by eco-san-genesys", coordinated by the National Institute of Economic Research "Costin C. Kirițescu”, Romania, in collaboration with ”Lucian Blaga” University of Sibiu, "Vasile Goldiş" West University Arad, S.C. GNIR Holding S.A. and S.C. SIAT S.A.

\section{REFERENCES}

1.Aebi, H., (1984): Catalase in vitro. Methods in Enzymology, 105: 121-126.

2.Arfan, M., Athar, H.R., Ashaf, M., (2007): Does exogenous application of salicylic acid through the rooting medium modulate growth and photosynthetic capacity in two differently adapted spring wheat cultivars under salt stress? Journal of Plant Physiology, 6(4): 685-694.

3.Ashraf, M., Harris, P.J.C., (2004): Potential biochemical indicators of salinity tolerance in plants. Plant Science, 166: 3-16.

4.Bates, S., (1973): Rapid determination of free proline for water stress studies. Plant and Soil, 39: $205-207$.

5.Fariduddin, Q., Hayat, S., Ahmad, A., (2003): Salicylic acid influences net photosynthetic rate, carboxylation efficiency, nitrate reductase activity and seed yield in Brasssica juncea. Photosynthetica, 41: $281-284$.

6.Gutiérrez-Rodríguez, M., Aristeo, C.P., San Miguel, Ch.R., Larqué-Saavedra, A., (1991): Stimulation of root growth by salicylic acid in carrot, radish and table beet. In: Abstracts of XVI International Botanical Congress. St. Louis, USA, pp. 652.

7.Gutiérrez-Coronado, M.A., Trejo-López, C., Larqué-Saavedra, A., (1998): Effects of salicylic acid on the growth of roots and shoots in soybean. Plant Physiology and Biochemistry, 36(8): 563-565.

8.Hayat, S., Fariduddin, Q., Ali, B., Ahmad, A., (2005): Effects of salicylic acid on growth and enzymes activities of wheat seedlings. Acta Agronomica Hungarica, 53: 433-437.

9.Hussein, M.M., Balbaa, L.K., Gaballah, M.S., (2007): Salicylic Acid and Salinity Effects on Growth of Maize Plants. Research Journal of Agriculture and Biological Sciences, 3(4): 321-328.

10.Kaydan, D., Yagmur, M., Okut, N., (2007): Effects of salicylic acid on the growth and some physiological characters in salt stressed wheat (Triticum aestivum L.). Tarim Bilimleri Dergisi, Ankara Universitesi Ziraat Fakultesi, 13(2): 114-119.

11.Khan, W., Prithiviraj, B, Smith, D.L., (2003): Photosynthetic responses of corn and soybean to foliar application of salicylates. Journal of plant physiology, 160: 485-492.

12.Kim, Y.H., Yoo, Y.J., (1996): Peroxidase production from carrot hairy root cell culture. Enzyme and microbial Tecnology, 18: 531-536.

13.Mishra, A., Choudhuri, M.A., (1999): Effect of salicylic acid on heavy metal-induced membrane degradation mediated by lipoxigenase in rice. Biologia Plantarum, 42: 409-415.

14.Moharekar, S.T., Lokhande, S.D., Hara, T., Tanaka, R., Tanaka, A., Chavan, P.D., (2003): Effect of salicylic acid on clorophyll and carotenoid contents of wheat and moong caryopsislings. Photosynthetica, 41: $315-317$.

15.Noreen, S., Ashraf, M., Hussain, M., Jamil, A., (2009): Exogenous application of Salicylic acid enhances antioxidative capacity in salt stressed Sunflower (Helianthus annuus L.) plants. Pakistan Journal of Botanical Sciences, 41(1): 473-479.

16.Purcărea, C., Cachiță, D., (2008a): Comparative studies about the influence of salicylic and acetylsalicylic acid on content of assimilatory pigments in the primary leaves of sunflower (Helianthus sp.) plantlets. Studia Universitatis Vasile Goldis, Arad, Seria Stiințele vieții, 18: 51-54.

17.Purcărea, C., Cachiță, D., (2008b): The influence of salicylic acid and acetylsalicylic acid on the growth of sunflower (Helianthus sp.) seedling roots and on their total absorption capacity. Studia Universitatis Vasile Goldis, Arad, Seria Stiințele vieții. 18: 55-60.

18.Santoro, M.M., Lau, Y., Khan, S.M.A., Hou L., Bolen, D.W., (1992): Increased thermal stability of proteins in the presence of natturally occuring osmolytes. Biochemistry Journal, 31: 5278-5283.

19.Sreenivasulu, N., Ramanjulu, K., Ramachandra-Kini, K., Prakash, H.S., Shekar-Shetty, H., Savithri, H.S., Sudhakar, C., (1999): Total peroxidase activity and peroxidase isoform as modified by salt stress in two cultivars of fox-tail millet with differential salt tolerance. Plant Science, 141: 1-9.

20.Waseem, M., Athar, H.U.R, Ashraf, M., 2006: Effect of salicylic acid applied through rooting medium on drought tolerance of wheat. Pakistan Journal of Botanical Sciences, 38(4): 1127-1136.

21.Xue, J., Zhang, A., Fang, Z., Sheng, W., (2006): The effect of Salicylic acid on the growth of Pinellia Ternate. The $11^{\text {th }}$ International Congress of Plant Tissue culture \& Biotechnology, China, pp. 96. 